Ege Tıp Dergisi / Ege Journal of Medicine 2021; 60 (3): 299-301

\title{
Dövme alanında molluskum kontagiozum
}

\section{Molluscum contagiosum in tattoo area}

\author{
İlgen Ertam Sağduyu (D) Bengü Gerçeker Türk B Tuğçe Özkapu (D) \\ Ege Üniversitesi Tıp Fakültesi Deri ve Zührevi Hastalıklar Anabilim Dalı, İzmir, Türkiye
}

\section{öz}

Dövme birçok dermatolojik probleme yol açabilmektedir. Bu problemler, güneşe hassasiyet, dövme pigmentine karşı alerji, Hepatit B, C ve İmmun Bağışıklık Yetmezliği Virüs (HIV) enfeksiyonları dışında diğer birçok viral ve bakteriyel enfeksiyonlardır. On yedi yaşında erkek hasta altı hafta önce başlayan, sağ ön kolda dövme alanında kabartılar nedeniyle başvurdu. Hastanın öyküsünden dört ay önce sağ ön koluna dövme yaptırdığı öğrenildi. Dermatolojik muayenede sağ ön kol dövme alanına sınırlı, umbilike, 1-2 mm boyutunda papüller izlenmekteydi. Özgeçmiş ve soy geçmişinde herhangi bir özellik bulunmamaktaydı. Histopatolojik incelemede viral inklüzyon cisimcikleri izlendi. Klinik ve histopatolojik bulgularla hastaya molluskum kontagiozum tanısı kondu.

Anahtar Sözcükler: Dövme, enfeksiyon, molluskum kontagiozum.

\section{ABSTRACT}

Tattoos cause many dermatological problems. These problems are sensitivity to sun, allergy to tattoo pigments, hepatitis B, C and Human Immune Deficiency Virus (HIV) infections and other viral and bacterial infections. A 17-year-old male presented with papules on the right arm tattoo area, which occurred six weeks ago. In his personal history, it was learned that he had a tattoo four months ago. In dermatological examination, 1-2 $\mathrm{mm}$ umbilicate papules on the right forearm tattoo area. There is no significance in his medical and family history. The histopathological examination revealed viral inclusion bodies. The diagnosis of molluscum contagiosum was made on clinical and histopathological findings.

Keywords: Tattoo, infection, molluscum contagiosum.

\section{GíRiş}

Dövme (tatuaj), son yıllarda giderek daha popüler bir hal almıştır. Bu artışla orantılı olarak gelişen komplikasyon oranları da artış göstermektedir. $\mathrm{Bu}$ komplikasyonlar inflamatuvar durumlar, enfeksiyonlar ve neoplazmlar şeklinde gruplandırılabilir. Bunlardan viral enfeksiyonlar molluskum kontagiozum (MK), verrü plana, verruka vulgaris (human papilloma virüs), Hepatit B (HBV) ve Hepatit C (HCV), İnsan Bağışık Yetmezlik Virüsü (HIV) şeklinde karşımıza çıkabilmektedir (1).
HBV ve HCV dövme yaptıranlarda önemli bir sorun olarak karşımıza çıkmaktadır. Bu virüslerin özellikle kontamine enjektör kullanımı ve profesyonel olmayan kişiler tarafından gerçekleştirilen işlem sonrasında daha fazla geliştiği bilinmektedir. Ancak dövme yaptıranlarda HBV ve HCV ile ilişkili kronik viral hepatit riskini araştıran bir çalışmada dövme bir risk faktörü olarak bulunamamıştır $(1,2)$.

Burada dövme alanında MK lezyonları gelişen bir olgu sunulmaktadır. 


\section{OLGU}

On yedi yaşında erkek hasta sağ ön kolda dövme alanına uyan bölgede kabartılar nedeniyle başvurdu. Öyküsünden dört ay önce sağ ön kola dövme yaptırdığı ve işlemden altı hafta sonra bu bölgede şeffaf kabarıklıklar geliştiği öğrenildi. Olgumuz, arkadaşı tarafından steril olmayan bir ortamda yaptırdığı dövme alanında MK lezyonlarının geliştiğini ifade etmekteydi.

Dermatolojik muayenede sağ ön kol dövme alanına sınırlı, umblike 1-2 $\mathrm{mm}$ boyutlarında papüller izlenmekteydi (Şekil-1a, 1b). Özgeçmiş ve soy geçmişinde herhangi bir özellik bulunmamaktaydı. Hastanın lezyonlarından yapılan histopatolojik incelemede, hücre sitoplazmasında viral inklüzyon cisimcikleri gözlendi (Şekil-1c). Molluskum kontagiozum tanısıyla hastanın lezyonları kürete edildi.

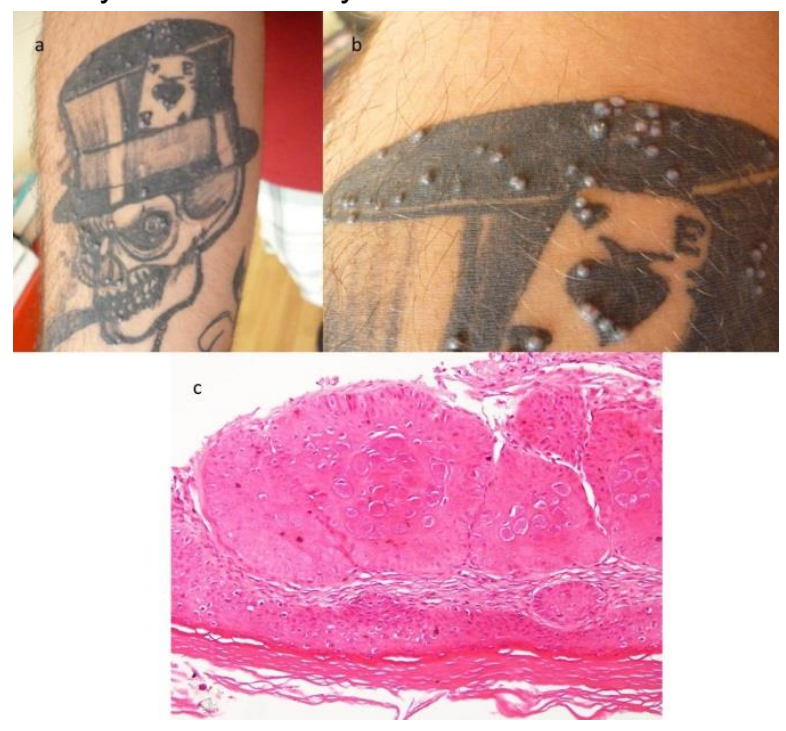

Şekil-1. (a) Dövme üzerinde izlenen beyaz renkte umblike papüller, (b) dövme üzerinde umblike papüllerin yakından görünümü, (c) epidermiste lobüler hiperplazi ve viral inklüzyon cisimcikleri (H\&E).

\section{TARTIŞMA}

Molluskum kontagiozum umblike papüllerle seyreden, etkeni pox virüs grubundan bir viral enfeksiyondur. Özellikle tropikal iklimlerde, atopik dermatit, Darier hastalığı ve immün yetmezlik gibi hastalıkların varlığında sıklığı artmaktadır (3). Sıklıkla çocuklarda gözlenir. Bulaşma tuvaletler ve kıyafetler aracılığıyla olabildiği gibi yüzme havuzlarından da olabilmektedir (4). Cinsel yolla bulaşabilen bir hastalık olması nedeniyle erişkinlerde gözlendiğinde hastalar bu yönüyle sorgulanmalıdır. Bu hastalarda primer olarak anogenital bölge tutulmaktadır. İmmun yetmezlikli hastalarda dissemine, atipik veya dev formlarda gözlenebilir (5). Ancak bağışıklık sistemi normal olan hastalarda dövme alanı üzerinde $M K$ lezyonları gelişen hastalar bildirilmiştir (3-5). Ayırıcı tanıda viral siğiller, pyojenik granülom, amelanotik melanom, bazal hücreli karsinom ve adneksiyal tümörler yer almaktadır. İmmun yetmezlikli hastalarda histoplazmoz, kriptokokkoz ve penisilliyozis de benzer görünümde olabilir (4). Lezyonlar genellikle kendiliğinden geriler. Tedavi olarak destrüktif (fiziksel ve kimyasal), \%5 imikimod gibi immunmodülatör ve antiviral tedavi uygulanabilir. Destrüktif tedavide küretaj, kriyoterapi ve topikal keratolik ajanlar kullanılabilir (3). Olgumuzda lezyonlar steril bir uçla açılarak küretaj işlemi uygulanmıştır.

Dövme işlemi, deride fiziksel bir hasar oluşturarak viral ve bakteriyel enfeksiyonların transdermal geçişine kolaylık sağlamaktadır (6). Dövmeye bağlı enfeksiyonların gelişiminde ortam hijyeninin yüksek standartlarda olmamasının yanı sıra bazı faktörler de bulunmaktadır. Bunlar, kullanılan mürekkebin kontaminasyonu ve dövme yapılacak deri bölgesinin yetersiz dezenfeksiyonudur. Bir diğer faktör ise, dövme sonrasındaki iyileşme sürecinde oluşan kaşıntı ve yanma nedeniyle bölgeyi kaşıma eylemi sonucunda süperinfeksiyon ve inokülasyon riskinin artmasıdır (6). Ancak dövme ile ilişkili enfeksiyon gelişiminde esas enfeksiyon kaynağı olarak mürekkebin rol oynadığı düşünülmektedir (7). Dövme yaptıran kişiler de bu konuda bilinçlendirilmelidir. Dövme sonrasında oluşabilecek enfeksiyon ve yan etkilerin bildirimi sağlıklı yürütülürse bu konuda daha iyi önlemler alınabilecektir (8).

Bununla birlikte literatürde dövme alanında MK gelişen çok az sayıda olgu bulunmaktadır. Olgumuz, arkadaşı tarafından steril olduğunu ifade ettiği bir iğne kullanılarak yapılan dövme alanında MK lezyonlarının geliştiğini ifade etmekteydi. $\mathrm{Bu}$ nedenle boya ile ilişkili kontaminasyon olabileceği düşünüldü. Boyanın içinde olduğu kabın ortak kullanıldığını ifade eden olgumuz, dövmenin steril ortamlarda yapılmasının önemini ortaya koymak ve bu yerlerin denetiminin gerekliliğini vurgulamak amacıyla sunulmuştur.

\section{SONUÇ}

Dövme (Tatuaj) işlemi hijyenik ortamda yapılmadığı takdirde enfeksiyonlara yol açabilir.

\section{Çıkar çatışması: Çıkar çatışması bulunmamaktadır.}




\section{Kaynaklar}

1. Juhas E, English JC 3rd. Tattoo-associated complications. J Pediatr Adolesc Gynecol. 2013; 26: 125-9.

2. Silverman AL, Sekhon JS, Saginaw SJ, Wiedbrauk D, Balasubramaniam M, Gordon SC. Tattoo application is not associated with an increased risk for chronic viral hepatitis. Am J Gastroenterol. 2000; 95: 1312-5.

3. De Giorgi V, Grazzini M, Lotti T. A three-dimensional tattoo: molluscum contagiosum. CMAJ. 2010 15; 182 : E382.

4. Grillo E, Urech M, Vano-Galvan S, Jaén P. Lesions on tattooed skin--a case study. Aust Fam Physician. 2012; 41: 308-9.

5. Molina L, Romiti R. Molluscum contagiosum on tattoo. An Bras Dermatol. 2011; 86: 352-4.

6. Wenzel SM, Rittmann I, Landthaler M, Bäumler W. Adverse reactions after tattooing: review of the literature and comparison to results of a survey. Dermatology. 2013; 226: 138-47.

7. Wollina U. Severe adverse events related to tattooing: an retrospective analysis of 11 years. Indian J Dermatol. 2012; 57: 439-43.

8. LeBlanc PM, Hollinger KA, Klontz KC. Tattoo Ink-Related Infections - Awareness, Diagnosis, Reporting, and Prevention. N Engl J Med. 201213; 367: 985-7. 